\title{
Coffee berry borer (Hypothenemus hampei Ferrari) trapping in coffee (Coffea arabica L.) with artisan traps at el Paraíso, Guerrero, Mexico
}

Hernández-Castro, Elias'; Sotelo-Nava, Héctor²; Godínez-Jaimes, Flaviano ${ }^{3}$; Durán-Trujillo, Yuridia ${ }^{1}$; García-Escamilla, Paul ${ }^{1^{*}}$; Valenzuela-Lagarda, José Luis ${ }^{4}$

\begin{abstract}
${ }^{1}$ Universidad Autónoma de Guerrero. Maestría en Ciencias Agropecuarias y Gestión Local. Tuxpan, Iguala, Guerrero, México. ${ }^{2}$ Universidad Autónoma del Estado de Morelos. Facultad de Ciencias Agropecuarias. Chamilpa, Cuernavaca, Morelos, México. ${ }^{3}$ Universidad Autónoma de Guerrero. Facultad de Matemáticas. Ciudad Universitaria Sur. Chilpancingo, Guerrero, México. ${ }^{4}$ Universidad Autónoma de Guerrero. Centro Regional de Educación Superior de la Costa Chica. Cruz Grande, Guerrero, México.
\end{abstract}

*Corresponding author: paul_ge@hotmail.com

\begin{abstract}
Objective: To evaluate three proportions of alcohol in traps with one and three windows and two different colors to capture Hypothenemus hampei Ferrari in Coffea arabica L. plants.

Design/methodology/approach: The experiment followed a completely randomized design with a complete factorial arrangement and four replications. From March to July 2007, three mixtures of ethyl: methyl alcohol were evaluated in different proportions (1: 0, 0:1 and 1: 1). In addition, green and transparent traps were used, designed with a single or three windows. The number of captured coffee berry borers, water loss, attractant evaporation and damaged fruits percentage was evaluated. The data were analyzed through an analysis of variance and a test of means differences (Tukey, $p \leq 0.05)$. Results: The mixture of ethyl: methyl alcohol 1: 1 was the best, with an average catch of 980 trapped - insects week $^{-1}$ The single window of transparent color traps was the most efficient to avoid water loss, with an average loss of 1,129.79 $\mathrm{mL}$ and $905 \mathrm{~mL}$ respectively.

Limitations on study/implications: The design and color of the traps did not influence the capture efficiency and the evaporation of the attractant during the evaluated months. Therefore, it should be further evaluated during other important phenological stages for the crop
\end{abstract}

Findings/conclusions: Transparent color traps with a window and 1: 1 ethyl: methyl alcohol were efficient for capturing H. hampei and lowering their population.

Keywords: Hypothenemus hampei Ferrari, Coffea arabica L., attractant, capture and coffee berry borer

\section{INTRODUCTION}

(Coffea arabica L.) is of great economic importance worldwide. In 2018 the average world production was 10,403,454 t. Brazil produced 3,556,638 t, followed by Vietnam 1,616,307 t,

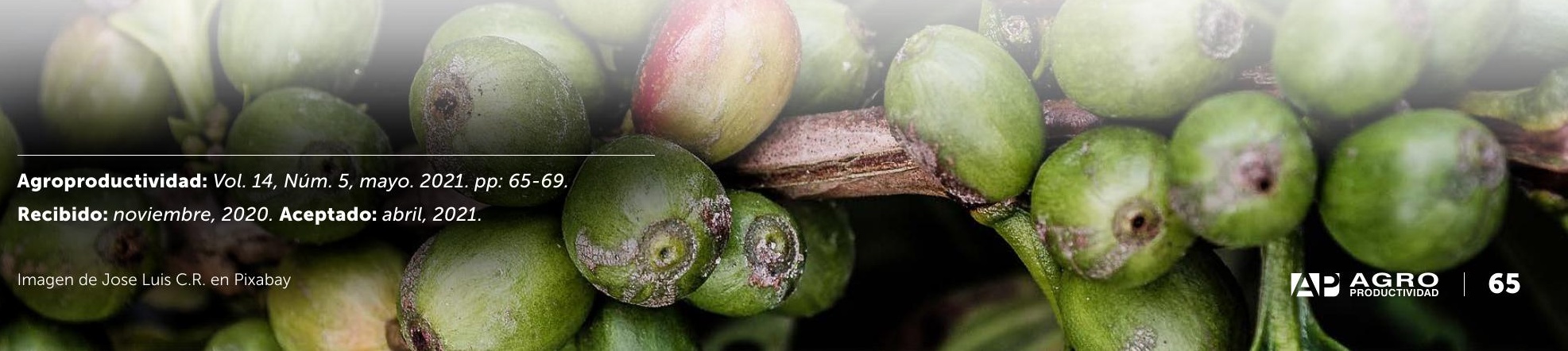


Indonesia 722,461 t, and Colombia 720,634 t. Mexico ranked eleventh with 158,325 t (FAO, 2020).

In 2018, Mexico registered a planted area of 21,163,051.24 ha, with an average production of 282,569 $t$ and an estimated commercial value of the production of $\$ 641,026,369.00$ (Mexican pesos). The state of Guerrero registered 45,839.05 ha distributed throughout the Costa Grande and Costa Chica regions (SIAP, 2018).

One of the serious phytosanitary problems that coffee presents is the attack of the coffee berry borer (CBB) (Hypothenemus hampei Ferrari), which causes losses of up to $80 \%$ of production (Benavides and Arévalo, 2002). This pest is endemic to central Africa and distributes in the coffee-growing regions of the world (Rosales et al., 1999). Most of the insect's life cycle is feeding on seeds or grains (Barrera, 2002; Barrera, 2013). Due to this, studies continue to develop technologies for its control and the insect's biology has been studied for better management strategies (Giraldo-Jaramillo et al., 2018). Tests have been carried out with chlorantraniliprole, an ingestion insecticide against coleopteran larvae with a new mode of action and low impact with other insects, such as bees. Cyantraniliprole is another insecticide with a mortality effect that affects the behavior of $\mathrm{H}$. hampei (Plata-Rueda et al., 2019A; Plata-Rueda et al., 2019B). In the field, the specimens are captured with attractant traps, where a single trap with methanol-ethanol can capture hundreds of insects per week (Barrera et al., 2008) and even with the use of terpenes as repellants (Góngora et al., 2020). Celestino et al. (2016) evaluated a wide variety of botanical oils, mineral oils and azadirachtin for the control of $\mathrm{H}$. hampei but these were not effective.

The objective of this research was to evaluate the effect of three concentrations of alcohol in traps with one and three windows and two different colors to capture $H$. hampei at El Paraíso, municipality of Atoyac de Álvarez, Guerrero, Mexico.

\section{MATERIALS AND METHODS Experiment location}

The research took place in a commercial coffee plantation at El Paraiso, Guerrero, Mexico, located between coordinates $17^{\circ} 38^{\prime}$ 91" LN, 100 19' 38" LW $1150 \mathrm{~m}$ above sea level. The region's climate is $\mathrm{A}(\mathrm{C}) \mathrm{W} 2$ semi-warm subhumid (INEGI, 2012; CESAVEGRO, 2013). The evaluation was carried out from March to July 2007. in a 3 ha area.

\section{Establishment of the experiment and design}

The plants under study were marked. The distance between traps was $20 \mathrm{~m}$. A completely randomized design was used in a complete factorial arrangement with four repetitions. The experimental units were the different alcohol proportions in each trap. The traps were placed on a secondary branch at a $1.50 \mathrm{~m}$ height; they were marked with a treatment and repetition number to identify and locate it.

\section{Traps crafting}

The traps were made with 2 L capacity polyethylene terephthalate-polyester (PET) containers (Figure 1A). For the single window traps $(5 \times 5 \mathrm{~cm}$; Figure $1 \mathrm{~B})$ a quadrangular cut was made in the middle of the containers. For the three-window traps, quadrangular holes of the same size were made, distributed in such a way that each window had a barrier in front that would cause an effect of knocking down the insects when they entered the interior of the trap (Figure 1C). The traps were distributed in the orchard as described (Figure 1D). Inside the trap, a dropper with the attractant was installed in the middle of the windows and secured with $A 35 \mathrm{~cm}$ wire at one end. The mixtures were previously prepared with the proportions of ethyl and methyl alcohol with the help of a syringe and the dropper was filled. With the other end of the wire, the trap was attached to the stem of the plant (Figure 1D)

\section{Treatments}

For the evaluation of the variable, three factors were considered: a) Trap design: with one and three windows, b) Trap color: green or transparent, and c) Proportions of ethyl and methyl alcohol: 1: 0, 0: 1 and 1: 1. The combination of these three factors generated 12 treatments shown in Table 1.

\section{Captured CBBs by treatments}

The number of captures per treatment was quantified to evaluate the effectiveness of the different treatments. The water from the traps was emptied into a container, separating the captured with a filter.

\section{Water and attractant loss by trap}

The water expenditure ( $\mathrm{mL}$ per week) was quantified with a graduated cylinder when changing the attractant in each trap, to see which lost more water.

The attractant remaining amount per trap was also measured with a graduated cylinder to assess the 
evaporation loss and calculate its periodicity for each design.

\section{Infestation percentage}

Four samples were taken per experimental unit, at a height of $1.5 \mathrm{~m}$ at each cardinal point, each with 25 coffee beans, of which the number of brocaded beans was recorded to calculate the percentage of infestation in each assessed plant.

\section{Statistical analysis}

A multivariate analysis of variance (MANOVA) was used with a factorial blocks design and the logarithmic transformation of the number of drilled seeds plus one to normalize the residuals. Subsequently, a means comparison was carried out using the Tukey test ( $\alpha=0.05$ ) to determine which factor levels were the best.

\section{RESULTS AND DISCUSSION}

Nineteen records were made of the number of borers captured per installed trap; the evaluations were weekly made.

\section{Captured borers by treatment}

The MANOVA results showed that the main effects of trap design, ethanol: methanol ratio and trap color were significant $(p=0.002, p=0.002$, $p=0.001$, respectively), but not the three interactions (Table 2).

\begin{tabular}{|c|c|c|c|}
\hline $\begin{array}{c}\text { No. } \\
\text { Treatment }\end{array}$ & Trap design & Alcohol & Color of the trap \\
\hline 1 & A window & 1:0 & green \\
\hline 2 & A window & $0: 1$ & green \\
\hline 3 & A window & 1:1 & green \\
\hline 4 & A window & 1:0 & transparent \\
\hline 5 & A window & $0: 1$ & transparent \\
\hline 6 & A window & 1:1 & transparent \\
\hline 7 & Three windows & $1: 0$ & green \\
\hline 8 & Three windows & $0: 1$ & green \\
\hline 9 & Three windows & 1:1 & green \\
\hline 10 & Three windows & 1:0 & transparent \\
\hline 11 & Three windows & $0: 1$ & transparent \\
\hline 12 & Three windows & 1:1 & transparent \\
\hline
\end{tabular}
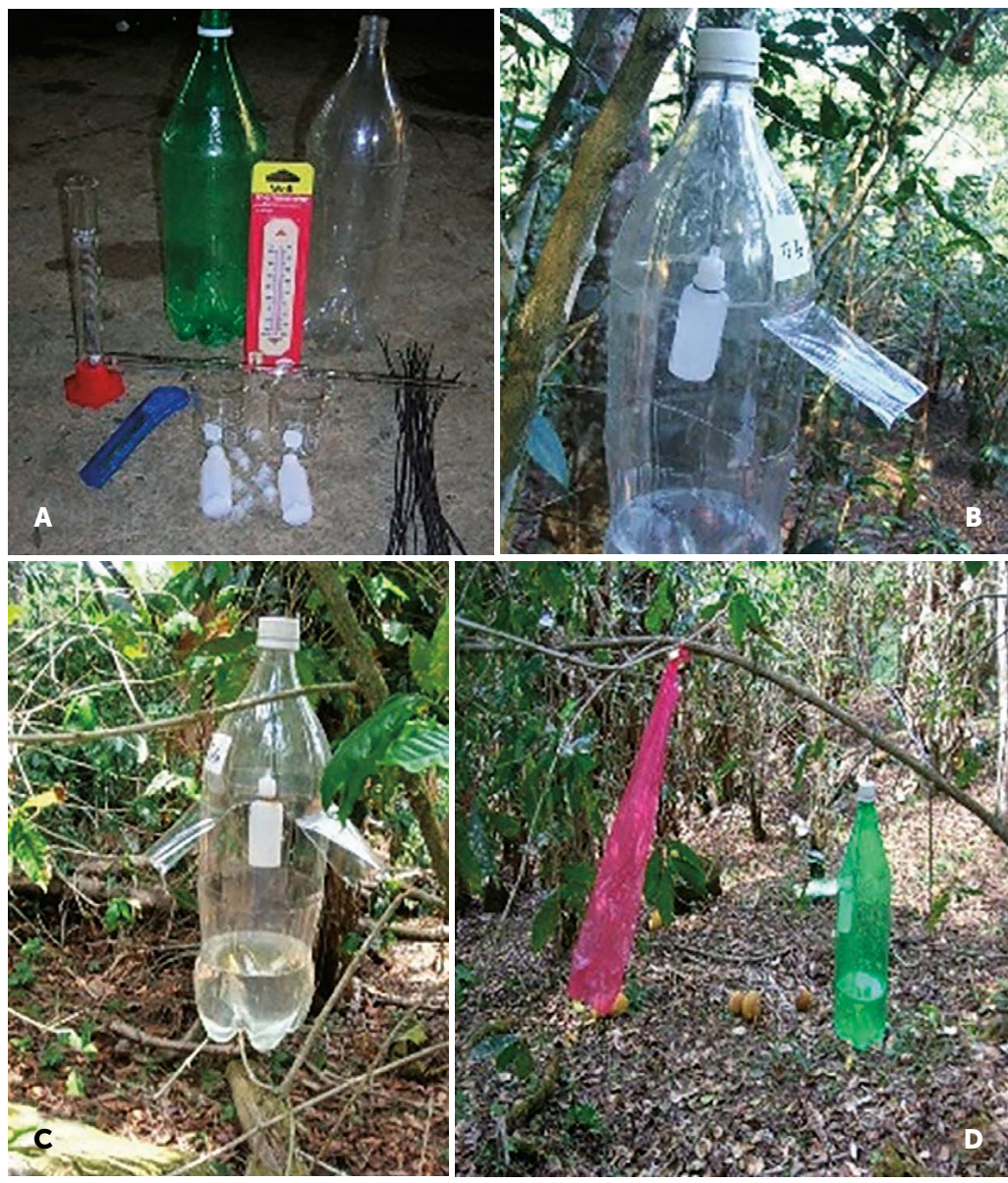

Figure 1. Traps to capture of H. hampei in El Paraíso, Guerrero, Mexico. A) Materials used; B) Trap with one window; C) Trap with three windows; D) Identification and placement of traps.

Regard the capture effectiveness for the coffee borer, it was observed that the ethanol: methanol 1: 1 ratio is the one that recorded the highest capture, an average of 980 trapped insects week 1, followed by 0: 1 and finally 1: 0 (Table 3). These results coincide with those observed by Fernández and Cordero (2005), where they evaluated different attractants and their methyl and ethyl alcohol treatment was superior to the others, with average 400 captured adults per week.

Regard the trap color, the transparent color captured a greater number than the green color. Finally, it is

\begin{tabular}{|c|c|c|}
\hline Source of variation & $\operatorname{Pr}>\mathrm{F}$ & Significance \\
\hline Design* Attractive proportions & 0.4506 & ns \\
\hline Design*Color & 0.4272 & ns \\
\hline Attractant proportions ${ }^{*}$ Color & 0.6480 & ns \\
\hline Design*Attractive proportions ${ }^{*}$ Color & 0.9624 & ns \\
\hline
\end{tabular}

* $P \leq 0.05 \quad * * P \leq 0.01 \quad$ ns: not significant 
observed that the design with three windows is better than the single window, which concurs with that reported by Barrera et al. (2008), who evaluated two types of traps (ETOTRAP ${ }^{\circledR}$ and ECOIAPAR ${ }^{\circledR}$ ) with a mixture of methanol: ethanol in a 3 : 1 ratio, respectively, concluded that the design of the trap influences the attraction efficiency.

The traps used in this study are an excellent tool to lower $\mathrm{H}$. hampei populations weekly and can be part of an integrated management strategy with other different techniques or tools because insecticide tests with new action pathways against larvae have been carried and have shown to be friendly with parasitoid insects, predators and pollinators (Plata-Rueda et al., 2019A). Insecticides such as Ciantraniliprole have lethal and sublethal effects that affect their behavior (Plata-Rueda et al., 2019B): and terpenes, botanical and mineral essential oils with insecticidal and repellent effects (Celestino et al., 2016; Etztli et al., 2019; Góngora et al., 2020) or the use of Bacillus thuringiensis for first instar larvae (López-Pazos et al., 2009).

\section{Water loss per trap}

It was observed that the weekly water loss by evaporation presented differences according to the design ( $P r>F=0.0001)$ and the color $(\mathrm{Pr}>\mathrm{F}=0.0415)$ of the trap, as well as the interaction of these $(\operatorname{Pr}>F=0.0121)$

The highest water loss occurred in the three window traps $(1,997.38 \mathrm{~mL}$ per week) than in the traps with single window ones (1,129.79 mL per week) (Table 4).

The observed differences in water loss were according to the color and the design of the traps. The transparent color presented less evaporation or loss of water (1,501.63 $\mathrm{mL}$ per week), while the green traps lost 1,625.54 $\mathrm{mL}$ per week. This can be attributed to the conditions of the coffee plantation, since, in shaded coffee

Proportions ethanol:methanol

Table 3. Efficiency of the proportions of alcohol in the capture of $\mathrm{H}$. hampei, in $\mathrm{El}$ Paraiso, Guerrero, Mexico.

Table 4. Water loss in $\mathrm{mL}$ per trap depending on the number of windows.

Design

Water loss ( $\mathrm{mL}$ )

Three windows

A window

$1,997.38$ a

Tukey's test $(p<0.05)$, values with the same letter in the column are not significantly different.
Number of coffee berry borer

plantations, the relative humidity is higher than in those exposed to the sun (PROCAFE, 2013). Regard the water loss in traps due the number of windows, differences were observed between the treatments, where the three windows design is statistically the same and different from the treatments of one window. Noting that the three window traps had a greater water loss (1,919.5 to 2,090.5 $\mathrm{mL}$ per week), while the single window traps recorded lower water loss (905.0 to 1,3056.5 mL per week) (Table 5).

\section{Loss of attractant by trap}

This estimation was made with the amount of the mixture per dropper at the time of installation of the traps of each of the treatments and the difference in the second reading at the time of removing the dropper from the trap. No difference was observed in the ethanol-methanol ratios, design and color of the trap, as well as their interactions. Unlike other research, when evaluating alcoholic attractants in artisanal traps to capture adult female coffee borers ( $H$. hampei), higher consumption of attractant was observed in the methanol: ethanol 1:1 treatment, the methanolethanol 3:1 treatment recorded higher captures than other treatments and a lower attractant consumption (Espinoza, 2013).
Table 5. Interactions of the design with the color of the trap in the loss of water.

\begin{tabular}{c|c|c|c} 
No. treatment & Trap (No. Windows) & Color of the trap & Water loss $(\mathrm{mL})$ \\
\hline 1 & 1 & green & $1,219.3 \mathrm{c}$ \\
\hline 2 & 1 & green & $1,235.5 \mathrm{c}$ \\
\hline 3 & 1 & green & $1,356.5 \mathrm{bc}$ \\
\hline 4 & 1 & transparent & $1,106.0 \mathrm{c}$ \\
\hline 5 & 1 & transparent & $905.0 \mathrm{c}$ \\
\hline 6 & 1 & transparent & $959.5 \mathrm{c}$ \\
\hline 7 & 3 & green & $2,047.0 \mathrm{a}$ \\
\hline 8 & 3 & green & $1,970.0 \mathrm{a}$ \\
\hline 9 & 3 & green & $1,928.0 \mathrm{a}$ \\
\hline 10 & 3 & Transparent & $2,029.3 \mathrm{a}$ \\
\hline 11 & 3 & Transparent & $2,090.5 \mathrm{a}$ \\
\hline 12 & 3 & Transparent & $1,919.5 \mathrm{ab}$ \\
\hline
\end{tabular}

Tukey's test $(p<0.05)$, values with the same letter in the column are not significantly different. 


\section{Infestation percentage}

The lowest infestation is observed in the 1:0 ethyl and methyl alcohol mixing ratio, with a mean of 0.9125 . The highest infestation was recorded with the $1: 1$ ratio of ethyl and methyl alcohol of 1.4375, respectively (Table 6).

It should be noted that CBBs catch is not directly proportional to the infestation percentage, because the attractant attracts CBBs from neighboring properties with high infestations, usually those abandoned.

\section{CONCLUSIONS}

The ratio of ethyl alcohol: methyl 1:1 presented the highest capture rate of the coffee berry borer ( $H$. hampei Ferrari). The trap color does not influence the H. hampei capturing, the evaporation of the attractant and the level of infestation. The traps with a single-window and a transparent color were the ones that recorded the least water loss.

\section{ACKNOWLEDGMENTS}

In memoriam and recognition of Pedro Araujo Castro ${ }^{\dagger}$.

\section{REFERENCES}

Barrera, J.F. (2002). La Broca del Café: Una plaga que llego para quedarse. Plagas del Café en Chiapas. Colegio de la Frontera Sur. 17-20

Barrera, J.F., Herrera, J., Chiu, M., Gómez, J. y Valle, M.J. (2008). La trampa de una ventana (ECOIAPAR) captura más Broca del Café Hypothenemus hampei, que la trampa de tres ventanas (ATOTRAP). Entomología Mexicana. 7: 619-624.

Barrera, J.F. (2013). Ficha técnica Broca del Café Hypothenemus hampei SENASICA-Dirección General de Sanidad Vegetal.

Benavides, P. y Arévalo, M. (2002). Manejo Integrado: una estrategia para el control de la broca del café en Colombia. CENICAF. 53(1): 39-48

Celestino, F.N., Pratissoli, D., Machado, L.C., Santos, H.J., Queiroz, V.T. \& Mardgan, L. (2016). Control of coffee berry borer, Hypothenemus hampei (Ferrari) (Coleoptera: Curculionidae: Scolytinae) with botanical insecticides and mineral oils. Acta Scientiarum. Agronomy, 38(1), 1-8. https://doi.org/10.4025/ actasciagron.v38i1.27430

CESAVEGRO, Comité Estatal de Sanidad Vegetal de Guerrero. (2013). Sistema de Información de Campañas Fitosanitarias (SICAFI). Campaña contra Broca del Café. Consulta realizada en https:// cesavegro.org.mx/plagas-del-cafeto/.

Espinoza, A.F. (2013). Evaluación de Atrayentes Alcohólicos en trampas artesanales para la captura de hembras adultas de broca del café Hypothenemus hampei (Ferrari) en la Estación Experimental de San Pedro de la loma-Coroico. Tesis de grado para obtener el título de: Licenciatura en Ingeniería Agronómica. La Paz-Bolivia.

Etztli, I.M., Reyes, S.F., Eliete, M.P., Claudinei, A.F., Plata, A.B., Picanço, M.C. \& Barbosa, C.A. (2019). Eucalyptus resinifera essential oils have fumigant and repellent action against Hypothenemus
Table 6. Level of infestation by $H$. hampei according to the ethyl: methyl alcohol ratios and the percentage of damaged fruits.

Proportion (ethyl:methyl) Infestation level (\%)

\begin{tabular}{c|c}
$1: 1$ & $1,4375 \mathrm{a}$ \\
\hline $0: 1$ & $1,2500 \mathrm{ab}$ \\
\hline $1: 0$ & $0.9125 \mathrm{~b}$ \\
\hline
\end{tabular}

Tukey's test $(p<0.05)$, values with the same letter in the column are not significantly different.

hampei. Crop Protection 116: 49-55. https://doi.org/10.1016/j. cropro.2018.09.018.

FAO, Food and Agriculture Organization (2020). FAO: Estadísticas. http://www.fao.org/faostat/es/?\#data/QC. Consultada el 08 de febrero del 2020.

Fernández, S. y Cordero, J. (2005). Evaluación de atrayentes alcohólicos en trampas artesanales para el monitoreo y control de la broca del café, Hypothenemus hampei (Ferrari). BIOAGRO. 17(3): 143148

Giraldo-Jaramillo, M., Garcia, G.A. \& Parra, R.J. (2018). Biology, Thermal Requirements, and Estimation of the Number of Generations of Hypothenemus hampei (Ferrari, 1867) (Coleoptera: Curculionidae) in the State of São Paulo, Brazil, Journal of Economic Entomology, 111(5): 2192-2200. https://doi. org/10.1093/jee/toy162

Góngora, C.E., Tapias, J., Jaramillo, J., Medina, R., Gonzalez, S., Casanova, H., Ortiz, A. \& Benavides, P. (2020). Evaluación de compuestos terpénicos volátiles repelentes al barrenador del café, Hypothenemus hampei (Ferrari) (Coleoptera: Curculionidae). J. Chem. Ecol. 46: 881-890. https://doi. org/10.1007/s10886-020-01202-5

INEGI (2012). Instituto Nacional de Estadística, Geografía e Informática. Gobierno del Estado de Guerrero, Anuario Estadístico del Estado de Guerrero. 601.

López-Pazos, S.A., Cortázar, J.A. \& Cerón, S.A. (2009). Cry1B and Cry3A are active against Hypothenemus hampei Ferrari (Coleoptera: Scolytidae). Journal of Invertebrate Pathology 101(3): 242-245.

Plata-Rueda, A., Martínez, L.C., Rodrigues, N.C., Cola, J., Sena, M.E., Serrão, J.E., Carvalho, R.N. \& Lemes, F. (2019A). Chlorantraniliprolemediated effects on survival, walking abilities, and respiration in the coffee berry borer, Hypothenemus hampei, Ecotoxicology and Environmental Safety, 172: 53-58. https://doi.org/10.1016/j. ecoenv.2019.01.063.

Plata-Rueda, A., Martínez, L.C., Da Silva, B.K., Zanuncio, J.C., Fernandes, M.D., Guedes, R.N. \& Fernandes, F.L. (2019B). Exposure to cyantraniliprole causes mortality and disturbs behavioral and respiratory responses in the coffee berry borer (Hypothenemus hampei). Pest Management Science. https://doi.org/10.1002/ ps.5358

PROCAFE (2013). Fundación Salvadoreña para Investigaciones en Café Consulta realizada en: http://www.procafe.com.sv/menu/ Generalidades/CondicionesAgroecologicas.htm

Rosales, M.M., Silva, A. y Rodríguez, G.G. (1999). Estrategia para el manejo integrado del minador de la hoja y la broca del fruto del café (en línea). FONAIAP

SIAP, Servicio de Información Agroalimentaria y Pesquera. (2018). www.siap.gob.mx. Consultada el 25 de febrero, 2018. 